\title{
Does Probe's Eye Subthalamic Nucleus Length on T2W MRI Correspond with Microelectrode Recording in Patients with Deep Brain Stimulation for Advanced Parkinson's Disease?
}

\author{
Derin Beyin Stimülasyonu Uygulanan Parkinson Hastalarında \\ T2W MR'da Probe Eye ile Ölçülen Subtalamik Nukleus Uzunluğu, \\ Mikroelektrod Kayatla Uyumlu mu?
}

Ersoy KOCABICAK ${ }^{1}$, Dursun AYGUN², Ilkay OZAYDIN², Ali JAHANSHAHI ${ }^{4}$, Sonny K. H TAN 5 , Musa ONAR², Omer BOKE ${ }^{6}$, Murat KURT ${ }^{7}$, Hatice GUZ $^{6}$, Murat TERZI ${ }^{2}$, Onur ALPTEKIN ${ }^{8}$, Yasin TEMEL ${ }^{9}$

${ }^{1}$ Ondokuz Mayis University, Faculty of Medicine, Department of Neurosurgery, Samsun, Turkey

${ }^{2}$ Ondokuz Mayis University, Faculty of Medicine, Department of Neurology, Samsun, Turkey

${ }^{3}$ Ondokuz Mayis University, Faculty of Medicine, Department of Radiology, Samsun, Turkey

${ }^{4}$ Maastricht University, Faculty of Medicine, Department of Neuroscience, Maastricht, Netherlands

${ }^{5}$ Aachen University, Faculty of Medicine, Department of Neurosurgery, Aachen, Germany

${ }^{6}$ Ondokuz Mayis University, Faculty of Medicine, Department of Psychiatry, Samsun, Turkey

${ }^{7}$ Ondokuz Mayis University, Faculty of Medicine, Department of Psychology, Samsun, Turkey

${ }^{8}$ Medtronic Inc., Neuromodulation, Istanbul, Turkey

${ }^{9}$ Maastricht University, Faculty of Medicine, Department of Neurosurgery, Maastricht, Netherlands

Corresponding Author: Ersoy KOCABICAK / E-mail: ersoykocabicak@gmail.com

\begin{abstract}
AIM: Subthalamic nucleus (STN) deep brain stimulation (DBS) has become a well-accepted treatment for patients with advanced Parkinson's disease (PD). During surgical planning for DBS, the length of the STN is taken into account and verified during microelectrode recording (MER) intraoperatively. Here, we addressed the question to which extent the length of the STN measured with the T2 weighted MRI in the probe's eye view corresponded with the intraoperatively determined length of the STN with MER.

MATERIAL and METHODS: We included 10 consecutive Parkinson's disease patients who underwent STN DBS surgery. The length of the STN in the probe's eye view mode was calculated along the trajectory of the central MER electrode crossing the STN.

RESULTS: Our analysis showed no statistical difference between the length of the STN measured with the T2 weighted probe's eye view mode and the MER (right STN length 5.8 $\pm 0.9 \mathrm{~mm}$ MRI vs. $6.3 \pm 0.5 \mathrm{~mm} \mathrm{MER,} \mathrm{p>0.05;} \mathrm{left} \mathrm{STN} \mathrm{length} \mathrm{5.6} \pm 0.4 \mathrm{~mm}$ MRI vs $5.8 \pm 1 \mathrm{~mm}$ MER, $p>0.05$ ). CONCLUSION: This means that the entry and the exit of the STN can be adequately estimated using the probe's eye view preoperatively. KEYWORDS: Parkinson's disease, Subthalamic nucleus, Microelectrode recording, Magnetic resonance imaging, Deep brain stimulation
\end{abstract}

öz

AMAÇ: STN DBS ilerlemiş Parkinson hastalığı olan hastaların tedavisinde kabul görmüş bir tedavi metodudur. Derin beyin stimülasyonunun (DBS) cerrahi planlaması yapılırken subtalamik nukleusun (STN) uzunluğu göz önünde bulundurulur ve intraoperatif olarak mikroelektrod kayıtla (MER) doğrulanır. Bu çalışmada T2 ağırlıklı MR'da probe eye ile ölçülen STN uzunluğunun intraoperatif MER'le ölçülen STN uzunluğu ile ne kadar örtüştüğünü araştırdık.

YÖNTEM ve GEREÇLER: STN DBS cerrahisi uygulanan 10 Parkinson hastasını inceledik. Probe eye görüntüdeki STN uzunluğu ve STN'i geçen santral MER elektrodunun trasesinin uzunluğu hesaplandı.

BULGULAR: Analizimiz T2 ağırlıklı probe eye görüntüdeki STN uzunluğu ile MER arasında istatistiksel açıdan anlamlı fark olmadığını gösterdi. SONUÇ: STN'nin giriş ve çıkış noktaları preoperatif probe eye görüntüsü kullanılarak doğru bir şekilde belirlenebilir.

ANAHTAR SÖZCÜKLER: Parkinson hastalığı, Subtalamik nukleus, Mikroelektrod kayıt, Manyetik rezonans görüntüleme, Derin beyin stimülasyonu 


\section{INTRODUCTION}

Subthalamic nucleus (STN) deep brain stimulation (DBS) has become a well-accepted treatment for patients with advanced Parkinson's disease (PD) $(4,8,10)$. The method of radiologically targeting the STN is an important factor in the surgical planning. Thus far different imaging methods are used based on experience and the availability of technologies ( 7 , $17,18)$. In general, there are three main approaches: indirect targeting based on standard stereotactic atlas coordinates, direct targeting using high resolution magnetic resonance images (MRI), and the combination of these two approaches $(1,3,16)$.

The STN can be visualized as a dark (iron-rich) structure on the T2 sequence of the MRI. The aim is to position DBS electrode in the dorsolateral motor part of the STN. While planning, the length of the STN is taken into account and verified during microelectrode recording (MER) intraoperatively. This brings up the question to which extent the length of the radiological STN and the electrophysiological STN overlap. Studies in which the relation between the MR-based STN and MERbased STN are investigated using the classical $x, y, z$ planes have revealed some varying results. $(5,14)$.

Here, we addressed the question to which extent the length of the STN measured with the T2-weighted MRI in the probe's eye view corresponded with the intraoperatively determined length of the STN with MER. We focused on the probe's eye view since this is the actual anatomical plane in which the electrodes reach and enter the STN.

\section{MATERIAL and METHODS}

We included 10 consecutive Parkinson's disease patients who underwent STN DBS surgery and were followed for at least 3 months postoperatively from September 2011 to June 2012. All patients underwent preoperative clinical assessments including the Unified Parkinson's Disease Rating Scale (UPDRS) parts I/II/III and IV, Schwab and England and Hoehn \& Yahr scoring in the medication on and off states. Preoperative neuropsychological and psychiatric assessments were also performed. Inclusion- and exclusion criteria have been described in previously (17). Informed consent was obtained from all patients, and STN DBS was approved by the local ethics committee.

\section{Preoperative Planning Phase}

All patients underwent MRI examination 3 days prior to surgery with turbo spin echo T1(TR 596 ms, TE 13 ms, slice thickness $1 \mathrm{~mm}$ with no gaps, matrix $256 \times 256$ pixels), T2 (TR $4000 \mathrm{~ms}$, TE: $90 \mathrm{~ms}$, slice thickness $2 \mathrm{~mm}$ with no gaps, matrix 256X256 pixels) axial and double-dose gadolinium-enhanced T1 axial MRI. All MRI scans were performed using a Siemens Magnetom Vision 1.5-Tesla MR scanner (Siemens, Erlangen, Germany) and the images were obtained from the vertex to the infraorbital level. In the morning of the operation, a Leksell $\mathrm{G}$ frame was mounted and a stereotaxic computerized tomography (CT) was performed without contrast with a slice thickness of $1 \mathrm{~mm}$ reaching from the inferior level of the orbit to the vertex (Aquillon 16 CT scanner, Toshiba, Tokyo, Japan). The next step was MRI and CT image fusion and calculation of the stereotactic coordinates (Framelink 5, Medtronic Inc. Minneapolis, USA). For indirect targeting of the STN we used the following stereotactic coordinates from the midcommissural point: $12 \mathrm{~mm}$ lat, $2 \mathrm{~mm}$ posterior, $4 \mathrm{~mm}$ inferior to the midcommissural line. Finally, we adjusted the final target by direct targeting and defining the dorsolateral motor part of the STN on T2W MR images (Figure 1A-E).

\section{Surgery}

Antiparkinsonian drugs were reduced in the course of few days and stopped $12 \mathrm{~h}$ before surgery. After the anesthesiological preparation with dexmedetomidine hydrochloride, a precoronal burr hole was made on the contralateral side with most severe PD symptoms and electrodes were introduced for MER (Leadpoint; Medtronic, Minneapolis, USA). We were especially careful during trajectory planning to avoid blood vessels. We typically used 5 microelectrodes, unless this was not possible because of vessels. Recordings were performed in 0.5-1-mm steps starting from $10 \mathrm{~mm}$ above the radiological defined target. This continued through the STN until STN activity disappeared (Figure 2). The electrode with the most typical STN pattern over the longest distance was selected for test stimulation. Intraoperative macrostimulation was performed with a frequency of $100 \mathrm{~Hz}$ and stimulus duration of $60 \mu \mathrm{s}$ in stepwise fashion every $2 \mathrm{~mm}$ within the electrophysiological borders of the STN. At each step, the stimulus intensity was increased at increments of $0.5 \mathrm{~V}$ until a desired clinical response or occurrence of unwanted side effects that were evaluated by a neurologist. The following clinical parameters were scored using the UPDRS: tremor (if present) and rigidity in all four extremities, finger taps, hand movements and/ or handgrips, and leg agility. When we obtained a positive clinical result with low stimulation amplitudes and sideeffects were absent or only present, at higher amplitudes, the test electrode was withdrawn and replaced by the quadripolar electrode (Model 3389; Medtronic, Minneapolis, USA). When we had no satisfying effect during test stimulation, another electrode was chosen clinical evaluation. This was, typically the trajectory with the second longest STN activity. The position of the quadripolar electrode was verified using fluoroscopy. Finally the electrode was fixed in the burr hole with methylmethacrylate and connected to an extension cable, which was externalized at a distance of approximately $7 \mathrm{~cm}$ posterior from the burr hole, and connected to an external pulse generator (Model 3625; Medtronic). The same procedure was performed on the contralateral side.

On the first postoperative day, all patients underwent T1W and T2W MRI to evaluate the position of the electrodes and detect (a) symptomatic bleedings or other structural complications. The images were evaluated by an independent neuroradiologist. On the second postoperative day, internalisation of the pulse generator (Activa PC; Medtronic, Minneapolis, USA) was performed under general anesthesia. 


\section{Postoperative Clinical Examination}

Patients underwent motor and neuropsychological examinations 3 months postoperatively. The UPDRS parts III and IV were also scored in the stimulation off / medication off and stimulation on / medication off states.

\section{Defining the Subthalamic Nucleus on Magnetic Resonance Imaging}

All MR images were analyzed by two observers, which showed a high interobserver reliability. The images were processed using the Framelink 5 software (Medtronic; Minneapolis,
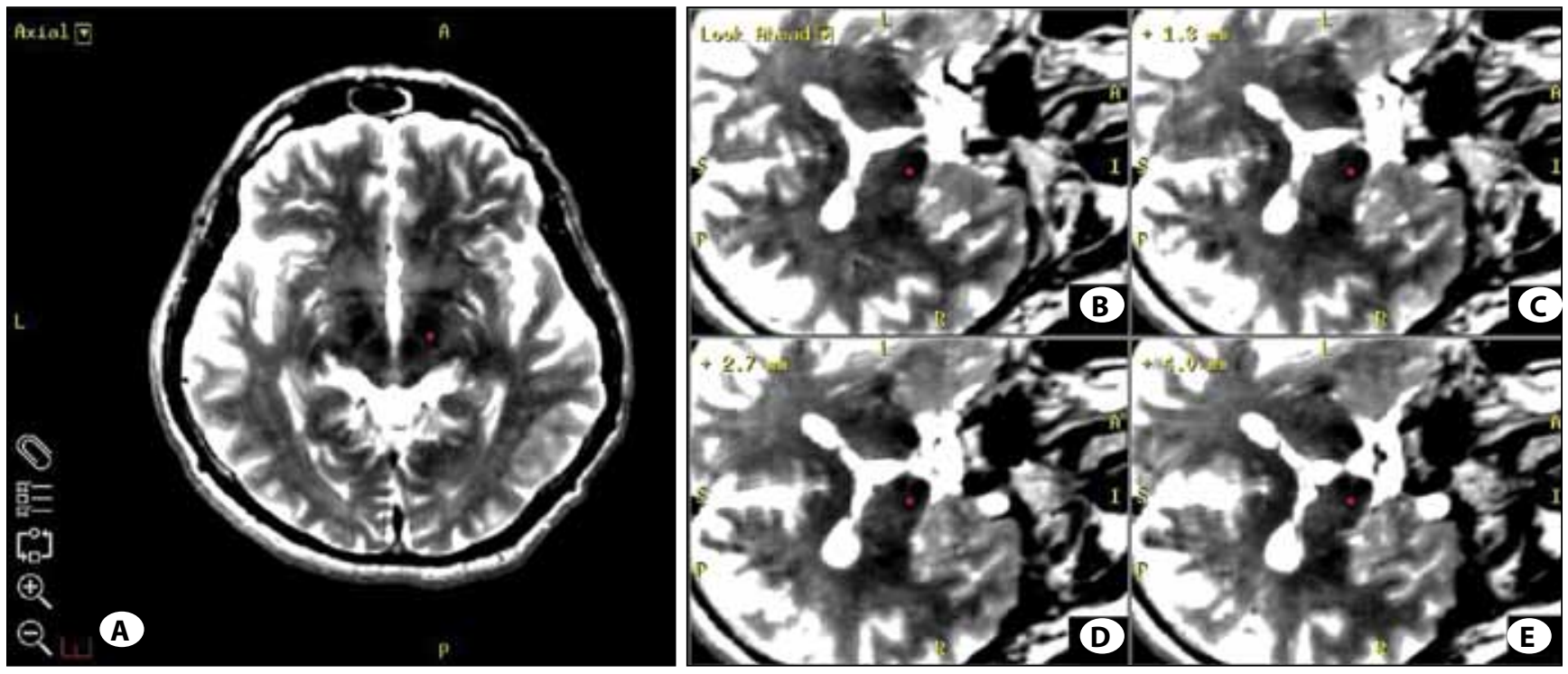

Figure 1: T2 weighted images at 1.5 Tesla (Siemens, Erlangen, Germany) showing the targeting of the dorsolateral part of the subthalamic nucleus (STN) in a patient with advanced Parkinson's disease. Please note the red point in the right STN in the images A-E. This illustrates the central trajectory. Image $\mathbf{A}$ is showing an axial image at the level of the target. The images B till $E$ show the probe's eye view of the central trajectory at the level of the target (B), $1.7 \mathrm{~mm}$ inferior or target (C), $2.7 \mathrm{~mm}$ inferior to target (D) and $4.0 \mathrm{~mm}$ inferior to target (E).

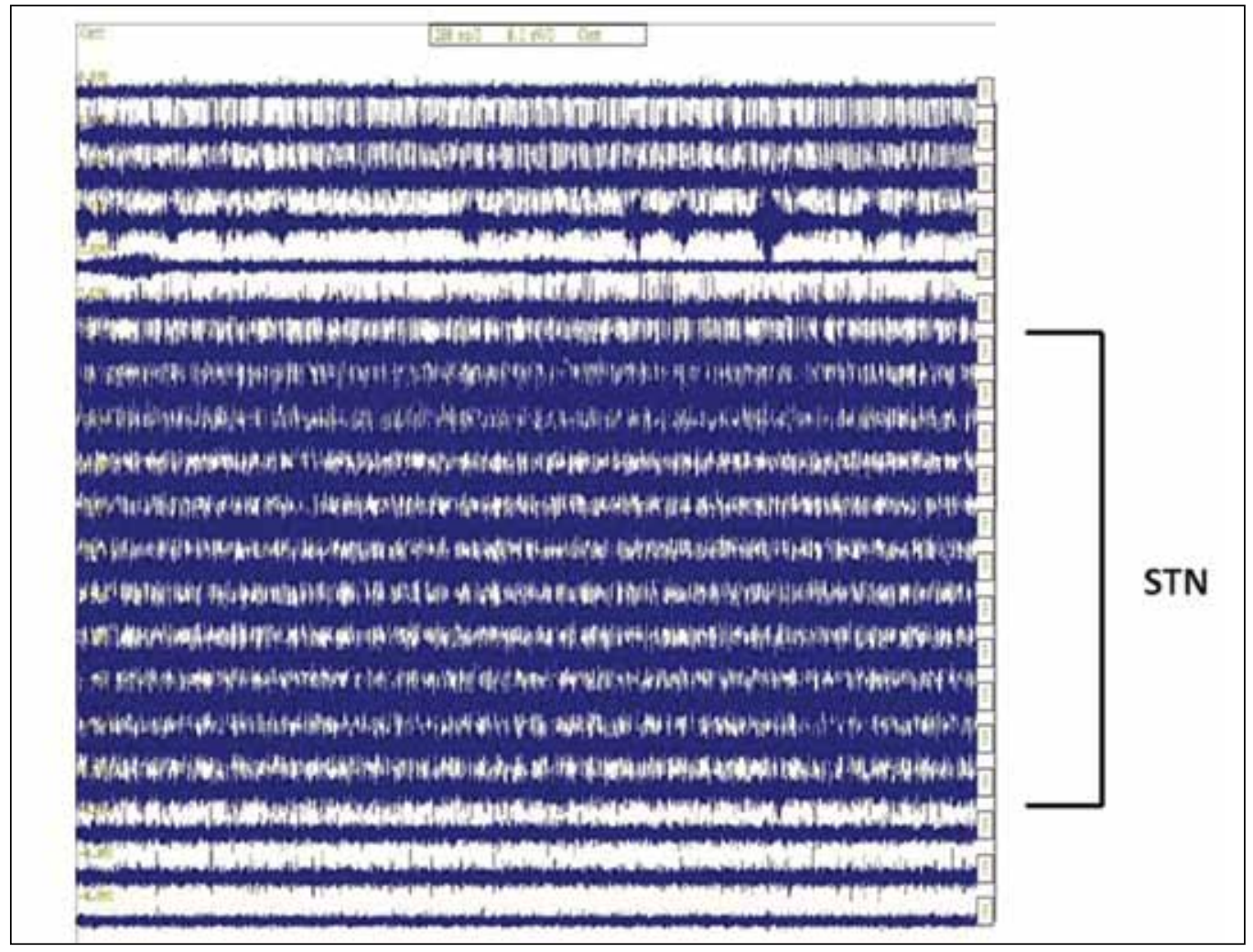

Figure 2: STN activity has been shown by the black line in central trajectory. Activity of the STN was typically characterized by a neuronal firing pattern consisting of increased baseline activity and a strong increase of highvoltage spikes, which were usually present over a length of 3-6 $\mathrm{mm}$. 


\begin{tabular}{|c|c|}
\hline 岁 & 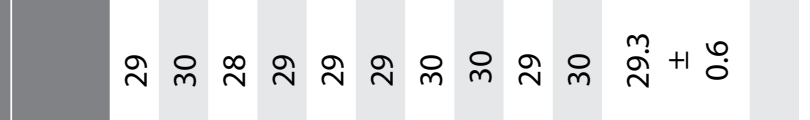 \\
\hline 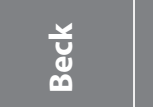 & 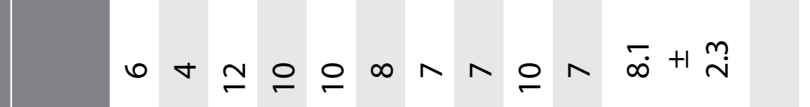 \\
\hline & 焉 こ \\
\hline $\bar{u} \frac{g}{\tilde{m}}$ & 迸 \\
\hline & 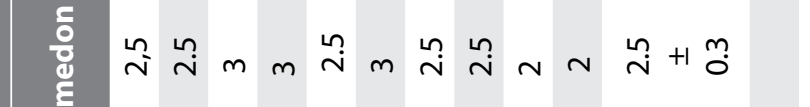 \\
\hline$I$ & 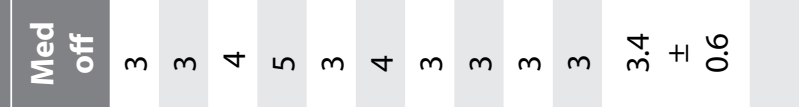 \\
\hline & 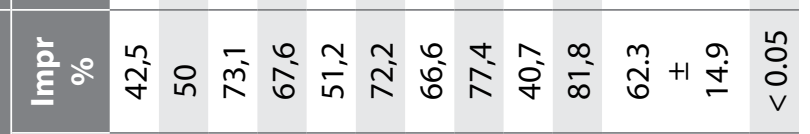 \\
\hline & 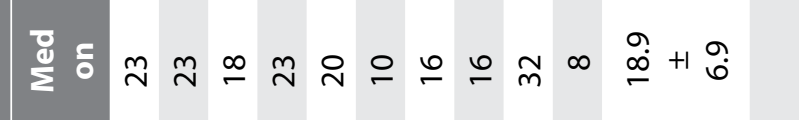 \\
\hline 峞 & 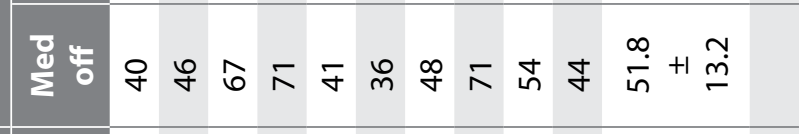 \\
\hline $\bar{\Xi}$ & 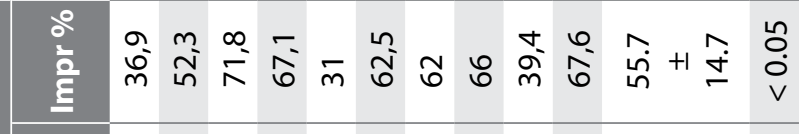 \\
\hline & 递 \\
\hline & 焉。 \\
\hline 酋 & 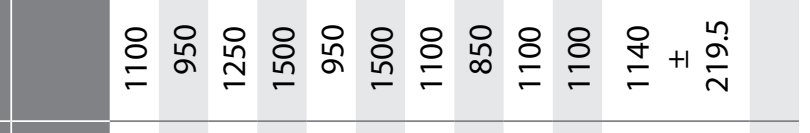 \\
\hline $\mathrm{a} \overline{\mathrm{z}}$ & 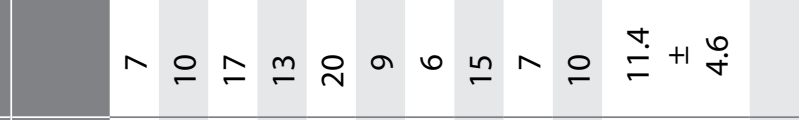 \\
\hline 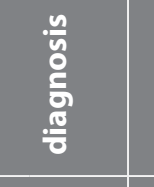 & 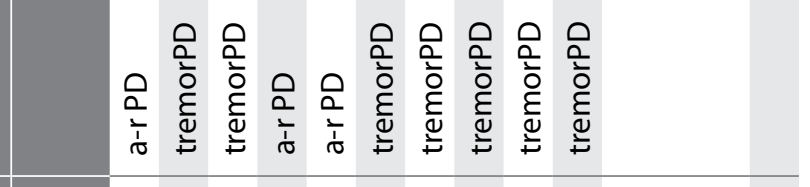 \\
\hline$\frac{\mathrm{g}}{\mathrm{g}}$ & 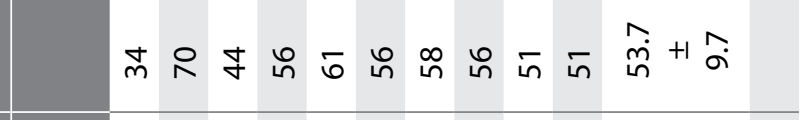 \\
\hline 扂 & $\varepsilon E \ldots+E E E \leftarrow$ \\
\hline 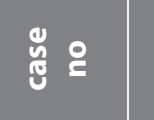 & 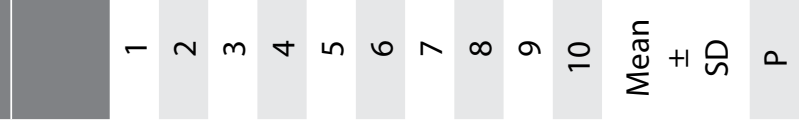 \\
\hline
\end{tabular}


USA). The observers determined the borders of STN on the probe's eye view MR T2W images and checked at each point simultaneously the position of the STN on sagittal, coronal and axial MR images. The length of the STN in the probe's eye view mode was calculated along the trajectory of the central MER electrode crossing the STN. The angles of the electrode trajectory between the entry point and the target point on the sagittal and coronal planes were also calculated in relation midcommissural line. In the superior-inferior direction the segmentation was stopped at the inferior border of the red nucleus, where the SNr begins.

\section{Defining the Subthalamic Nucleus with Microelectrode Recordings}

The electrophysiological length of the STN was defined by the trajectory of the central MER electrode. This was regardless of how many MER electrodes were used.

Typical STN activity was characterized by a neuronal firing pattern consisting of increased baseline activity and a strong increase of high-voltage spikes.

\section{Statistical Analysis}

Data are presented as means \pm standard deviations (SD) and were analyzed using the Wilcoxon signed ranks test. The level of statistical significance was defined as $P<.05$. All data were analysed using the SPSS 15.0 software package (version 15.0).

\section{RESULTS}

\section{Patient Characteristics}

The characteristics of the patients are provided in Table I. The age ranged from 34-70 years (mean: $53.7 \pm 9.7$ years). Seven patients presented with tremor-dominant type of PD and 3 patients with akineto-rigid type. The duration of the disease from the first diagnosis to the operation ranged from 6 to 20 years (mean: $11.4 \pm 4.6$ years).

\section{Clinical Outcome at 3 Months}

There was a substantial improvement of the total UPDRS score at 3 months post-operatively induced by STN DBS in the medication off condition. For details and changes in UPDRS part III scores, please see Table IV. One patient developed a temporary hemiballismus, which resolved in the course of few days, and another patient showed temporary signs of hypomania.

\section{Radiological Length of the Subthalamic Nucleus}

The average coronal and the sagittal angle for approaching the right STN were respectively $27.5^{\circ} \pm 10.1^{\circ}$ and $41.8^{\circ} \pm$ $12.6^{\circ}$, and for the left STN $32.4^{\circ} \pm 4.4^{\circ}$ and $41.5^{\circ} \pm 5^{\circ}$. Based on the MRI calculations, the mean length of the STN on the right side was $5.8 \pm 0.9 \mathrm{~mm}$ and on the left side $5.6 \pm 0.4 \mathrm{~mm}$. All individual lengths and grouped data for both sides are presented in Tables II, III.

\section{Electrophysiological Length of the Subthalamic Nucleus}

The mean length of the STN activity on the right side was 6.3 $\pm 0.5 \mathrm{~mm}$ and on the left side $5.8 \pm 1 \mathrm{~mm}$. For all individual lengths and grouped data for both sides please see Tables II, III.

\section{Comparing the STN Length Determined with Probe's Eye View MRI and MER}

Our analysis showed no statistical difference between the length of the STN measured with the T2 weighted probe's eye view mode and the MER (right STN length $5.8 \pm 0.9 \mathrm{~mm} \mathrm{MRI}$ vs. $6.3 \pm 0.5 \mathrm{~mm} \mathrm{MER,} \mathrm{p>0.05;} \mathrm{left} \mathrm{STN} \mathrm{length} 5.6 \pm 0.4 \mathrm{~mm}$ MRI vs $5.8 \pm 1 \mathrm{~mm}$ MER, p>0.05) (Table II, III).

\section{DISCUSSION}

Our results show that the radiological size of the STN obtained by $\mathrm{T} 2 \mathrm{~W}$ MR images is similar to the electrophysiological size obtained intraoperatively. This means that the entry and the exit of the STN can be adequately estimated using the probe's eye view preoperatively. It is known that in the classical $x, y$, and $z$ planes the radiological borders of the STN can be visualised well, except for the caudal border towards the substantia nigra pars reticulata (SNr). This can be difficult as SNr and some fibers related the STN are also seen as hypointense $(14,20)$. To clarify grey-white matter distinction and improve image quality, we used T2W images with $2 \mathrm{~mm}$ slice thickness.

The clinical improvement found in this study is in line with previous publications $(3,7,10,12)$. In our study population we observed one case of transient hemiballismus and one case of transient hypomania after STN DBS. These have been described before $(9,13,15)$.

The relevance of MER is a subject of debate and investigation. There are some suspicions about the necessity of MER as MRI techniques keep on improving and direct STN targeting preoperatively is successful. Additionally, there are some publications claiming that it increases the risk of complications like ICH although there are contrary publications $(2,6,17,19)$. Also demonstrated here, the anatomical length of the STN can be shown reliably with the preoperative MR imaging. Do we need MER to find the STN? The answer is probably no, but we think that we need MER to be able to determine which other trajectory should be used if the central trajectory does not deliver sufficient therapeutic effect or debilitating side effects during intraoperative test stimulation. This decision can be based on the information from MER. The trajectory showing the second longest STN activity can be tested and this can be if necessary extended to the third and so on. In the series presented here, we have implanted in circa $70 \%$ of the patients the final electrode in the central trajectory. In other series, this value was lower (17). 
Table II: Entry and Exit Points of the STN According to the Target Point on the Right and Left Side Evaluated by Probe's Eye View MRI and Microelectrode Recording of the Central Electrode

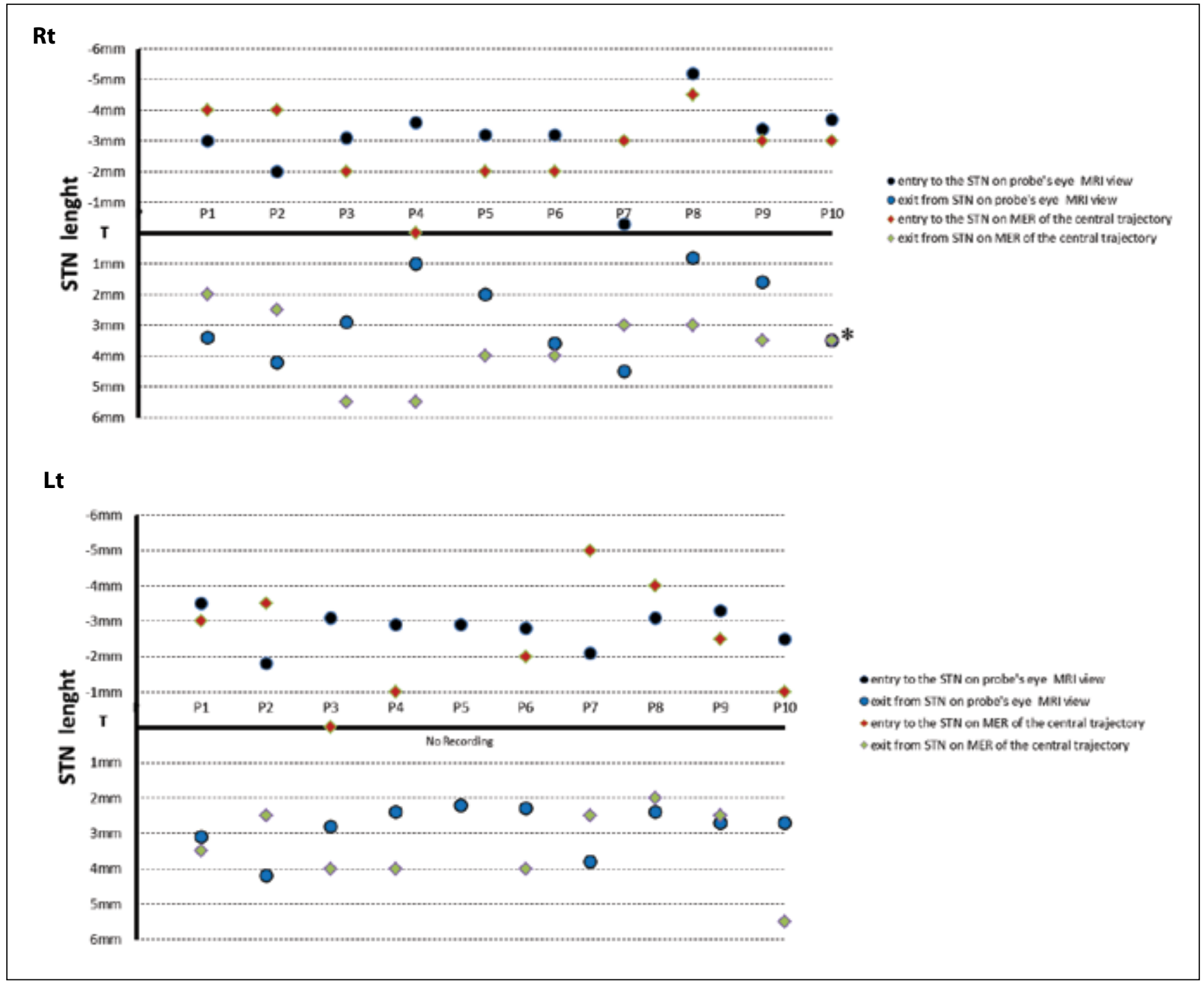

A: Right side, B: Left side, $\mathbf{T}$ : Target, $\mathbf{P}$ : Patient

Table III: Comparison of mm Values of Preoperative Probe's Eye View Magnetic Resonance Imaging and Intraoperative Microelectrode Recording Measurements

\begin{tabular}{|c|c|c|c|}
\hline & $M R_{(\mathrm{mm})}$ & $\operatorname{MER}_{(\mathrm{mm})}$ & $\mathbf{P}$ \\
\hline Rt pre target STN length & $3,1 \pm 1,2$ & $2.7 \pm 1.3$ & 0,859 \\
\hline Rt post target STN length & $2.7 \pm 1.3$ & $3.6 \pm 1$ & 0,11 \\
\hline Rt total STN length & $5.8 \pm 0.9$ & $6,3 \pm 0,5$ & 0,083 \\
\hline Lt pre target STN length & $2.8 \pm 0.5$ & $2.4 \pm 1.6$ & 1 \\
\hline Lt pre target STN length & $2.8 \pm 0.6$ & $3.3 \pm 1.1$ & 0,44 \\
\hline Lt total STN length & $5,6 \pm 0,4$ & $5,8 \pm 1$ & 0,779 \\
\hline
\end{tabular}

Rt: Right side, Lt: Left side, $\mathbf{P}: p$ value. 
Table IV: Patients'Total UPDRS, UPDRS III Scores, Leva-Dopa Drug Dosage in Med -Ona nd Med-Off State at the end of Three Months

\begin{tabular}{|c|c|c|c|c|c|c|c|c|c|}
\hline \multirow{2}{*}{$\begin{array}{c}\text { Case } \\
\text { no }\end{array}$} & \multicolumn{3}{|c|}{ UPDRS total } & \multicolumn{3}{|c|}{ UPDRS III } & \multicolumn{3}{|c|}{ LEDD } \\
\hline & $\begin{array}{l}\text { stim off } \\
\text { med off }\end{array}$ & $\begin{array}{l}\text { stim on } \\
\text { med off }\end{array}$ & impr \% & $\begin{array}{l}\text { stim off } \\
\text { med off }\end{array}$ & $\begin{array}{l}\text { stim on } \\
\text { med off }\end{array}$ & impr \% & Preop & Postop & impr \% \\
\hline 1 & 112 & 69 & 38.4 & 68 & 43 & 32.4 & 1100 & 562.5 & 48.9 \\
\hline 2 & 65 & 35 & 48.4 & 43 & 18 & 58.1 & 950 & 500 & 44.2 \\
\hline 3 & 114 & 40 & 64.9 & 68 & 18 & 73.5 & 1250 & 625 & 50 \\
\hline 4 & 136 & 110 & 19,1 & 72 & 58 & 19,4 & 1500 & 937.5 & 37.5 \\
\hline 5 & 63 & 54 & 17,4 & 44 & 25 & 43.1 & 950 & 500 & 47.3 \\
\hline 6 & 66 & 40 & 56.5 & 36 & 18 & 50 & 1500 & 850 & 43.3 \\
\hline 7 & 67 & 20 & 70.1 & 44 & 14 & 73.1 & 1100 & 562.5 & 48.8 \\
\hline 8 & 102 & 20 & 80.3 & 72 & 15 & 79.1 & 850 & 375 & 55.8 \\
\hline 9 & 66 & 27 & 59 & 40 & 17 & 57.5 & 1100 & 437.5 & 60.2 \\
\hline 10 & 73 & 35 & 52 & 44 & 18 & 59 & 1100 & 625 & 43.1 \\
\hline meanSD & $86.4 \pm 26.9$ & $45 \pm 27.2$ & $48.3 \pm 21.3$ & $53.1 \pm 14.8$ & $24,4 \pm 14.4$ & $54.4 \pm 17.9$ & $1140 \pm 219.5$ & $597.5 \pm 175.5$ & $48.2 \pm 6.4$ \\
\hline$P$ & & & $<0.05$ & & & $<0.05$ & & & $<0.05$ \\
\hline
\end{tabular}

\section{REFERENCES}

1. Acar F, Miller JP, Berk MC, Anderson G, Burchiel KJ: Safety of anterior commissure-posterior commissure-based target calculation of the subthalamic nucleus in functional stereotactic procedures. Stereotact Funct Neurosurg. 85(6):287-291, 2007

2. Binder DK, Rau GM, Starr PA: Risk factors for hemorrhage during microelectrode- guided deep brain stimulator implantation for movement disorders. Neurosurgery 56(4): 722-732, 2005

3. Deuschl G, Schade-Brittinger C, Krack P, Volkmann J, Schäfer $H$, Bötzel K, Daniels $C$, Deutschländer A, Dillmann U, Eisner W, Gruber D, Hamel W, Herzog J, Hilker R, Klebe S, Kloss M, Koy J, Krause M, Kupsch A, Lorenz D, Lorenzl S, Mehdorn HM, Moringlane JR, Oertel W, Pinsker MO, Reichmann H, Reuss A, Schneider GH, Schnitzler A, Steude U, Sturm V, Timmermann L, Tronnier V, Trottenberg T, Wojtecki L, Wolf E, Poewe W, Voges J; German Parkinson Study Group, Neurostimulation Section: A randomized trial of deep-brain stimulation for Parkinson's disease. N Engl J Med 355:896-908, 2006

4. Follett KA, Weaver $F M$, Stern $M$, Hur $K$, Harris $C L$, Luo $P$, Marks WJ Jr, Rothlind J, Sagher O, Moy C, Pahwa R, Burchiel K, Hogarth P, Lai EC, Duda JE, Holloway K, Samii A, Horn S, Bronstein JM, Stoner G, Starr PA, Simpson R, Baltuch G, De Salles A, Huang GD, Reda DJ; CSP 468 Study Group: Pallidal versus subthalamic deep-brain stimulation for Parkinson's disease. N Engl J Med 362(22):2077-2091, 2010

5. Hamani C, Richter EO, Andrade-Souza Y, Hutchison W, SaintCyr JA, Lozano AM: Correspondence of microelectrode mapping with magnetic resonance imaging for subthalamic nucleus procedures. Surg Neurol 63(3):249-253, 2005

6. Hariz MI: Safety and risk of microelectrode recording in surgery for movement disorders. Stereotact Funct Neurosurg 78: 146-157, 2002
7. Krack P, Batir A, Van Blercom N, Chabardes S, Fraix V, Ardouin C, Koudsie A, Limousin PD, Benazzouz A, LeBas JF, Benabid $A L$, Pollak P: Five-year follow-up of bilateral stimulation of the subthalamic nucleus in advanced Parkinson's disease. $\mathrm{N}$ Engl J Med 349:1925-1934, 2003

8. Limousin P, Pollak P, Benazzouz A, Hoffmann D, Le Bas JF, Broussolle E, Perret JE, Benabid AL: Effect of parkinsonian signs and symptoms of bilateral subthalamic nucleus stimulation. Lancet 345: 91-95, 1995

9. Mandat TS, Hurwitz T, Honey CR: Hypomania as an adverse effect of subthalamic nucleus stimulation: Report of two cases. Acta Neurochir 148(8):895-897; discussion 898, 2006

10. Odekerken VJ, van Laar T, Staal MJ, Mosch A, Hoffmann CF, Nijssen PC, Beute GN, van Vugt JP, Lenders MW, Contarino MF, Mink MS, Bour LJ, van den Munckhof $P$, Schmand BA, de Haan RJ, Schuurman PR, de Bie RM: Subthalamic nucleus versus globus pallidus bilateral deep brain stimulation for advanced Parkinson's disease (NSTAPS study): A randomised controlled trial. Lancet Neurol 12(1):37-44, 2012

11. Pollak P, Benabid AL, Gross C, Gao DM, Laurent A, Benazzouz A, Hoffmann D, Gentil M, Perret J: Effects of the stimulation of the subthalamic nucleus in Parkinson disease. Rev Neurol 149:175-176, 1993

12. Rodriguez-Oroz MC, Moro E, Krack P: Long-term outcomes of surgical therapies for Parkinson's disease. Mov Disord 27(14):1718-1728, 2012

13. Schilbach L, Weiss PH, Kuhn J, Timmermann L, Klosterkötter J, Huff W: Pharmacological treatment of deep brain stimulation-induced hypomania leads to clinical remission while preserving motor benefits. Neurocase 18(2):152-159, 2102 
14. Schlaier JR, Habermeyer $C$, Warnat J, Lange $M$, Janzen A, Hochreiter A, Proescholdt M, Brawanski A, Fellner C: Discrepancies betweentheMRI-and theelectrophysiologically defined subthalamic nucleus. Acta Neurochir 153(12):23072318, 2011

15. Spiegel J, Fuss G, Backens M, Reith W, Magnus T, Becker G, Moringlane JR, Dillmann U: Transient dystonia following magnetic resonance imaging in a patient with deep brain stimulation electrodes for the treatment of Parkinson disease. Case report. J Neurosurg 4: 772-774, 2003

16. Starr PA, Vitek JL, DeLong M, Bakay RA: Magnetic resonance imaging-based stereotactic localization of the globus pallidus and subthalamic nucleus. Neurosurgery 44(2): 303-313; discussion 313-314, 1999

17. Temel $Y$, Wilbrink $P$, Duits $A$, Boon $P$, Tromp S, Ackermans $L$, van Kranen-Mastenbroek V, Weber W, Visser-Vandewalle V: Single electrode and multiple electrode guided electrical stimulation of the subthalamic nucleus in advanced Parkinson's disease. Neurosurgery 61: 346-355; discussion 355-357, 2007
18. Temel $Y$, Prinsenberg $T$, Visser-Vandewalle V: Imaging of the subthalamic nucleus for deep brain stimulation: A systematic review. Neuromodulation 11(1):8-12, 2008

19. Xiaowu $H$, Xiufeng J, Xiaoping $Z$, Bin $H$, Laixing $W$, Yiqun C, Jinchuan L, Aiguo J, Jianmin L: Risks of intracranial hemorrhage in patients with Parkinson's disease receiving deep brain stimulation and ablation. Parkinsonism Relat Disord 16(2):96-100, 2010

20. Zhu XL, Hamel W, Schrader B, Weinert D, Hedderich J, Herzog J, Volkmann J, Deuschl G, Müller D, Mehdorn HM: Magnetic resonance imaging-based morphometry and landmark correlation of basal ganglia nuclei. Acta Neurochir 144(10):959-969, 2002 